\title{
Isolation, Identification and Antibiotic Sensitivity Pattern of Salmonella spp from Locally Isolated Egg Samples
}

\section{Md. Atikur Rahman', Azizul Haque ${ }^{2}$, Tasnim Ahmad ${ }^{3}$, Shahriar Mahmud ${ }^{3}$, Shaharuq Nahid Sohana ${ }^{3}$, Md. Rajib Hossain ${ }^{4}$, Nirmal Chandra Barman ${ }^{3}$, Md Badiruzzaman ${ }^{5}$, Tofajjal Hossain ${ }^{6}$, Md. Sherajul Haque ${ }^{6}$, Md. Ekhlas Uddin ${ }^{7}$, and Rokeya Ahmed ${ }^{1}$}

${ }^{1}$ Dept. of Microbiology, Gono Bishwabidyalay, Dhaka, Bangladesh; ${ }^{2}$ Dept. of Microbiology, University of Chittagong, Bangladesh; ${ }^{3}$ Dept. of Biotechnology and Genetic Engineering, Islamic University, Bangladesh; ${ }^{4}$ Dept. of Environmental Science \& Disaster Management, BSMRSTU, Gopalganj, Bangladesh; ${ }^{5}$ Dept. of Biochemistry and Molecular Biology, University of Dhaka, Bangladesh; ${ }^{6}$ Dept. of Physiotherapy, Gono Bishwabidalay, Dhaka, Bangladesh; ${ }^{7}$ Dept. of Biochemistry and Molecular Biology, Gono Bishwabidyalay, Dhaka, Bangladesh

*Correspondence: microaziz95@gmail.com

\section{ABASTRACT}

Salmonella have been found to be the major food borne disease in the world with a serious public health problem. The presence of any serotype of Salmonella in food under that food unfit for human consumption. Poultry eggs are considered as major sources for these pathogenic microorganisms. The current study was carried out to isolate and identify the Salmonella spp from egg sample collected from different retailer markets and farm of Savar area, Bangladesh. Antibiotic susceptibility test was also done to determine the resistance pattern. A total of 50 poultry eggs were examined. Salmonella spp, were isolated by culturing on selective plate and characterized by biochemical tests. In the present study the average prevalence of Salmonella was found to be $100 \%$ from outer surface of eggs and $20 \%$ from eggs yolk. All identified isolates were tested for antibiotic susceptibility to six commonly used antimicrobials by disk diffusion technique. The highest percentage of resistance $(60 \%)$ was found to Chloramphenicol, Ampicillin, Gentamicin and Tetracycline. Salmonella isolated from egg surface were found more antibiotic resistant than that of egg yolk. The present study suggests that poultry eggs are potential reservoir of antibiotic resistant Salmonella.

Keywords: Salmonella, Antibiotic sensitivity, Isolation, Egg, Pattern, and Food borne diseases.

\section{INTRODUCTION}

Salmonellosis is primarily a food poisoning syndrome, which occurs when ingesting pathogenic Salmonella serotypes. Salmonella have been known to cause illnesses for more than 100 years when it was discovered by Dr. Daniel Salmon (Yan et al., 2003). Eggs are laid by female animals of many different species, including birds, reptiles, amphibians, mammals and fish (Kenneth et al., 2017). The egg is comprised of 32-35\% yolk, 52-58\% albumen and $9-14 \%$ shell. The yolk contains about 60 Calories; three times the energy content of the egg white, Egg white consists 
primarily of about $90 \%$ water into which is dissolved 10 percent proteins. Due to their protein content, the United States Department of Agriculture categorizes eggs as Meats within the Food Guide Pyramid (Kenneth et al., 2017).

Despite the nutritional value of eggs, there are some potential health issues arising from cholesterol content, Salmonella contamination and allergy to egg proteins. Salmonella is capable can cause a variety of disease syndromes: enteric fever, bacteremia, enter colitis, and focal infections. Salmonella enteric is a bacterial pathogen that causes enteric fever and gastroenteritis in humans and animals (Didelot et al., 2011). Typhoid or enteric fever is an acute illness with incubation period 2 or 3 weeks, often characterized by high fever of about $40^{\circ} \mathrm{C}$, malaise and abdominal pain (Gonzalez-Escobedo et al., 2011), continual headache, diarrhea appears only during the second or third week (Tortora et al., 2011). There are two possible routes of bacterial contamination of egg; vertical and horizontal (De Reu et al., 2008). Vertical transmission takes place in the Trans ovarian route where the yolk, albumen and membranes are directly contaminated as a result of bacterial shedding from the infection of hen's reproductive organs, which takes place before the shell covers the eggs (Messens et al., 2005). Horizontal contamination begins with the passage of the eggs through the highly contaminated cloaca area at the moment of lay and leads to the shells be penetrated by microorganisms (De Reu et al., 2008; Md et al., 2014 ).

\section{MATERIALS AND METHODS}

Sampling, Samples Collection and Storage: The samples were collected during the study period from July to December 2017, at different region of Savar, Dhaka. The samples were collected by
In recent years, the prevalence of Salmonellosis in breeder flock, commercial broiler, and layer flocks is increasing day by day. Egg shells may additionally become contaminated from any surface with which it comes into contact. The hen's are released in an environment with a temperature of approximately $\left(68^{\circ} \mathrm{F}\right)$, where they cool immediately and their content contracts creating a negative pressure inside which can allow for the contaminant to move through the shell (De Reu et al., 2008). To avoid the contamination, eggs should be refrigerated at $4^{\circ} \mathrm{C}$ and cooked to an internal temperature of $71^{\circ} \mathrm{C}$ or hotter. Salmonella is one of the major bacterial agents that cause food borne infection in humans leading food borne disease worldwide (Herikstad et al., 2002).

The human health concern is the risk of direct transfer of resistant human pathogens via the food chain. S. Enteritis's came to prominence as a major food borne pathogen in Europe and America during the 1980s (Cogan and Humphrey, 2003). Human infections are usually associated with animal contact and the consumption of contaminated food products such as poultry egg, meat and other dairy products are food poisoning by Salmonella (William et al., 2003). Salmonella infection is one of the major constraints of poultry farming that hindered its development in Bangladesh (Kamaruddin et al., 2012). Therefore, Salmonellosis status of a farm needs to be determined for its proper control and management (Ahmed et al., 2008). The main objective of this study is to isolate and identify and determine the antibiotic resistance pattern of isolated Salmonella spp from poultry eggs of local farms and retailers in Savar.

aseptic technique using sterile zipper bags, gloves, etc. The microbiological analysis was conducted in the Department of Microbiology, Gono Bishwabidyalay, Savar, Dhaka. Total 50 samples 
were collected from different egg retailers and farm house. During collection of the eggs, it was ensured that cross contamination was minimized Isolation and Identification of Salmonella spp on Selective Agar: After collection of samples, outer shell surface washed with $70 \%$ alcohol and air dried then crack with a sterile knife. Egg yolk were also prepared and enriched in selenite cystein broth.

Each egg's content was mix thoroughly and homogenized and incubates at $37^{\circ} \mathrm{C}$ for 24 hours. At the end of selective enrichment, sample was streaked on selective media such as Xylose lysine deoxycholate (XLD) agar, Salmonella-Shigella (SS) and Rappaport Vassiliadis agar. Solidification of the medium was tested their sterility by incubation at $37^{\circ} \mathrm{C}$ for overnight to cheek their sterility and then in refrigerator for future use (Cappuccino et al., 2005).

The agar itself will turn red due to the presence of Salmonella type colonies and No heavy greyish swarming zone is visible in a Salmonella negative sample, whereas Salmonella positive samples give a very heavy swarming, at MSRV agar.

Microscopic Study by Gram's Staining Method: Gram staining method was used to distinguish and classify bacterial species into two large groups.

\section{Biochemical Tests for the Confirmation of Salmonella spp:}

Indole Test - Indole test demonstrates the ability of certain bacteria to decompose amino acid tryptophan to indole, which accumulates the medium. Tryptophan is hydrolyzed by tryptophan's to produce three possible end products, one of which is indole. Indole production is detected by Kovac's reagent which contains 4(p)-dimethyl amino Benz aldehyde; this reacts with indole to produce a red color. by taking precautions at all stages such as sampling, transportation and storage of the eggs. Samples are stored at $4^{\circ} \mathrm{C}$ temperature.

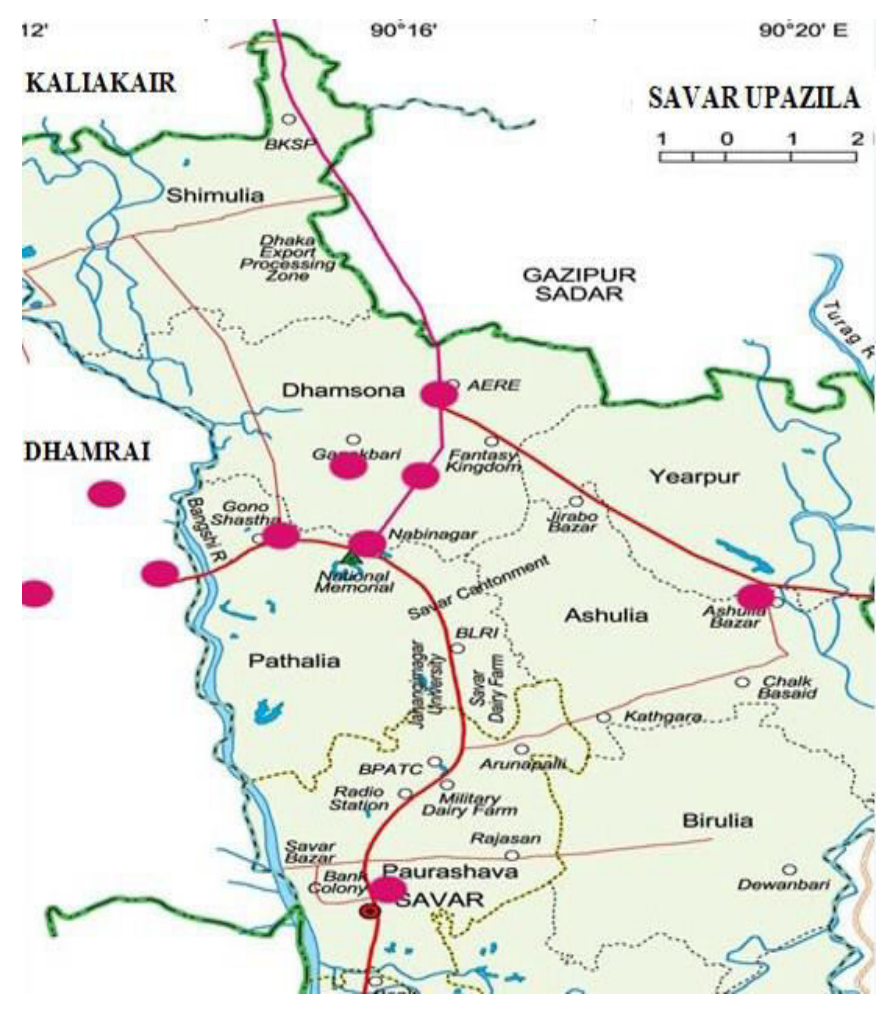

Fig 1: Sampling site at different areas in Savar Upazila of Dhaka city.

Gram's staining of the pure culture was performed according to method described by Aneja et al. (2003).

\section{Methyl Red-Voges Proskauer (MR-VP) Test -} MR-VP test detects the production of sufficient acid during the fermentation of glucose. Mixed acids fermentation results in accumulation of a variety of acids and a significant drop in the $\mathrm{pH}$ of the medium.

The medium used is MR VP broth. A nutrient medium with $0.5 \%$ Glucose added. This medium is also used for the Voges-Proskauer test, which determines acidic fermentation products results for growth. 
Citrate Test - Citrate test is used to test an organism's ability to utilize citrate as a source of energy. The $\mathrm{pH}$ indicator is Bromo thymol blue, which is green at neutral $\mathrm{pH}$, yellow at acidic $\mathrm{pH}<6.0$ and turns blue at alkaline $\mathrm{pH}>7.6$.

Oxidase Test - This detects the presence of a cytochrome oxidase system that will catalyze the transport of electrons in the bacteria. In the oxidase test, artificial electron donors and acceptors are provided. When the electron donor is oxidized by cytochrome oxidase it turns a dark purple. This is considered a positive result.

Catalase Test - This test demonstrates the presence of catalase, an enzyme that catalyzes the release of oxygen from hydrogen peroxide. This enzyme detoxifies hydrogen peroxide by breaking it down into water and oxygen gas. The bubbles resulting from production of oxygen gas clearly indicate a catalase positive result.

TSI Test - The triple sugar Iron (TSI) is a microbiological test roughly named, which is used to differentiate among the different groups of Enterobacteriaceae, based on their ability to ferment glucose, lactose and/or sucrose and to produce hydrogen sulfide. It is often used in the selective identification of enteric bacteria.

Urease Test - This test is used to determine the ability of an organism to split urea, through the production of an enzyme Urease. It identifies those organisms that are capable of hydrolyzing urea to produce ammonia and carbon dioxide. Urease is a constitutively expressed enzyme that hydrolyzes urea to carbon dioxide and ammonia (Cappuccino et al., 2005)

$$
\left(\mathrm{NH}_{2}\right)_{2} \mathrm{CO}+\mathrm{H}_{2} \mathrm{O}=\mathrm{CO}_{2}+2 \mathrm{NH}_{3}
$$

\section{Antibiotic Sensitivity test for Salmonella Spp:} Antibiotic susceptibility testing (AST) is usually carried out to determine which antibiotic will be most successful in treating a bacterial infection in vivo, testing for antibiotic sensitivity is often done by the Kirby-Bauer method. Place agar plates right side up in an incubator heated to $37^{\circ} \mathrm{c}$ for 10 to 20 minutes with the covers adjusted so that the plates are slightly opened. Inoculate all agar plates with their respective test organisms as follow; dip a sterile cotton swab into a well-mixed saline test culture and removes excess inoculated by processing the saturated swab against the inner wall of the culture tube. Allow all culture plates to dry for about 5 minutes. Gently press each disc down with the wooden end of a cotton swab or sterile, forceps to ensure that the discs adhere to the surface of the agar. Finally incubate all plate cultures in an inverted position for 24 hours at $37^{\circ} \mathrm{C}$. In this study, all the samples were tested for the susceptibility against five different commercially available antibiotics.

Table 1: Details of the drug, reference zone of inhibition based on clinical laboratory standards.

\begin{tabular}{|l|l|l|l|l|}
\hline \multirow{2}{*}{ Drug } & Disc potency $(\boldsymbol{\mu g})$ & \multicolumn{3}{|l|}{ Diameter of zone of inhibition(mm) } \\
\cline { 3 - 5 } & & Susceptible & Intermediate & Resistant \\
\hline Ciprofloxacin & $5 \mu \mathrm{g}$ & $\mathrm{S}:>31 \mathrm{~mm}$ & $\mathrm{I}: 21-30 \mathrm{~mm}$ & $\mathrm{R}:<20 \mathrm{~mm}$ \\
\hline Ampicillin & $10 \mu \mathrm{g}$ & $\mathrm{S}:>17 \mathrm{~mm}$ & $\mathrm{I}: 14-16 \mathrm{~mm}$ & $\mathrm{R}:<13 \mathrm{~mm}$ \\
\hline Chloramphenicol & $30 \mu \mathrm{g}$ & $\mathrm{S}:>18 \mathrm{~mm}$ & $\mathrm{I}: 13-14 \mathrm{~mm}$ & $\mathrm{R}:<12 \mathrm{~mm}$ \\
\hline Tetracyclin & $30 \mu \mathrm{g}$ & $\mathrm{S}:>15 \mathrm{~mm}$ & $\mathrm{I}: 12-14 \mathrm{~mm}$ & $\mathrm{R}:<10 \mathrm{~mm}$ \\
\hline Co-trimoxazole & $25 \mu \mathrm{g}$ & $\mathrm{S}:>30 \mathrm{~mm}$ & $\mathrm{I}: 28 \mathrm{~mm}$ & $\mathrm{R}:<22 \mathrm{~mm}$ \\
\hline Gentamicin & $10 \mu \mathrm{g}$ & $\mathrm{S}:>15 \mathrm{~mm}$ & $\mathrm{I}: 13-14 \mathrm{~mm}$ & $\mathrm{R}:<12 \mathrm{~mm}$ \\
\hline
\end{tabular}




\section{RESULT AND DISCUSSION}

\section{Isolation and identification of Salmonella spp:}

Eggs and egg products are nutritious foods and they form an important part of the human diet. In this present study 50 poultry eggs were examined for the isolation and identification of Salmonella spp. Inoculation was done from both shell and internal content of each egg sample. Among them 50 (100\%) samples from eggshell were found positive for Salmonella spp and only 10 (20\%) samples from internal content were found positive for Salmonella spp (Table 2).

Selenite cysteine broth: Selenite broth is used as a selective medium for the isolation of Salmonella species. Selenite Broth is used as a selective enrichment for the cultivation of Salmonella spp. Selenite broth gives pale or colorless colonies. The growth of Salmonella Spp in Selenite crystal broth was characterized by diffused turbidity of the broth (Fig 4).

Salmonella-Shigella agar: Salmonella-Shigella agar is a differential, selective medium for the isolation of Shigella and Salmonella species from pathological specimens, suspected foodstuffs, etc. Salmonella spp to grow sodium Thiosulfate and Ferric Citrate permit detection of hydrogen sulfide by the production of colonies with black centers and Shigella produced colorless smooth colony in SS agar.

XLD agar: XLD agar is a selective growth medium used in the isolation of Salmonella and Shigella species from clinical samples and from food. Two agar media Salmonella-Shigella agar, Xylose Lysine Deoxycholate agars were used for the identification and isolation of Salmonella species from egg samples.
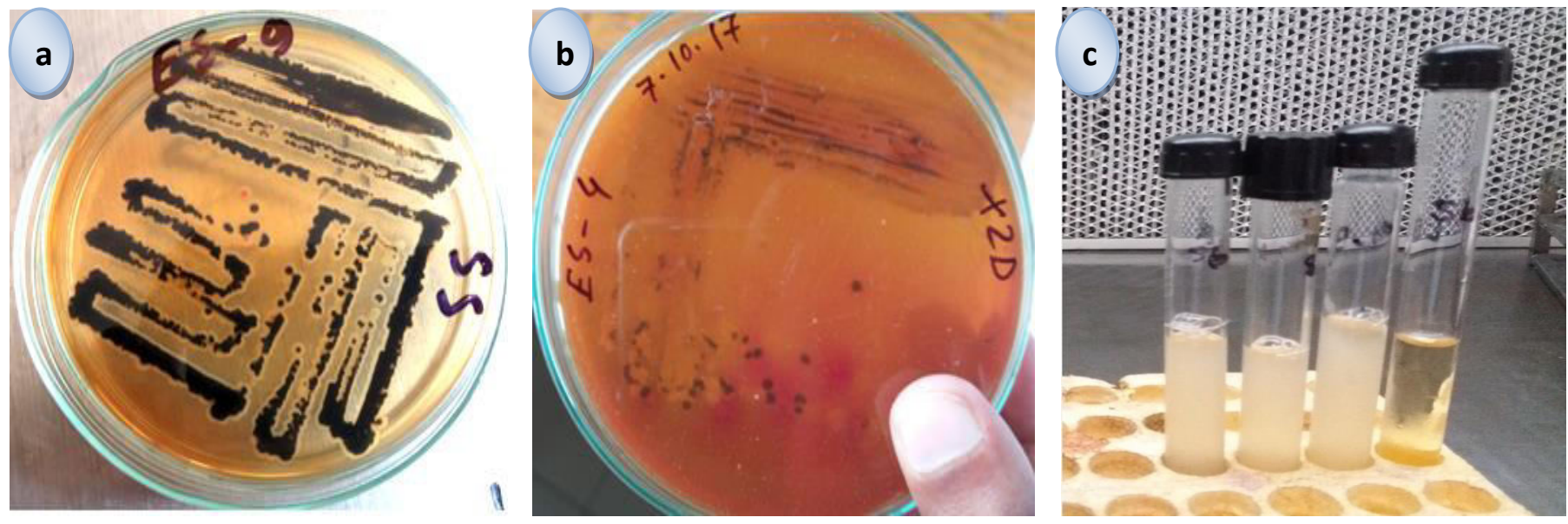

Fig 2: (a) Growth of Salmonella in Salmonella-Shigella agar medium; (b) Growth of Salmonella in XLD agar medium; and (c) Growth of Salmonella Spp in Selenite crystal broth.

Table 2: Percentage of Salmonella in total collected sample.

\begin{tabular}{cccc}
\hline $\begin{array}{c}\text { Sample } \\
\text { collection site }\end{array}$ & $\begin{array}{c}\text { Number of } \\
\text { samples }\end{array}$ & $\begin{array}{c}\text { Number of Salmonella } \\
\text { positive (egg shell })\end{array}$ & $\begin{array}{c}\text { Number of Salmonella positive } \\
\text { (eggs yolk ) }\end{array}$ \\
\hline Egg & 50 & $50(100 \%)$ & $10(20 \%)$ \\
\hline
\end{tabular}


Result of Gram Staining: In gram's staining under microscope, the organism's revealed gram negative, pink color; small rod shaped appearance, arranged in single, paired or chain form. (Fig 3)

Biochemical characterization of organisms: The biochemical identification of the organism was done by performing the biochemical tests. The biochemical tests were done as stated on Berge's Manual of Determinative Bacteriology. Result of different biochemical tests are given below:

TSI test: A bacterium that is non-lactose fermenter and ferments glucose, initially causes a yellow slant/yellow bottom (acid/acid reaction) after 8 hours but then converts to a red slant/yellow bottom after 24 hours. The whole sample tubes covered with black color due to excess production of $\mathrm{H}_{2} \mathrm{~S}$.

Citrate Test: Bacteria are inoculated on a medium containing sodium citrate and a $\mathrm{pH}$ indicator such as bromothymol blue. Use of citrate involves the enzyme citrase, which breaks down citrate to oxaloacetate and acetate. The isolated bacteria Salmonella will be citrate positive. All of the isolated Salmonella utilize citrate and change the color of the media green to blue (Alkaline).

Methyl Red test: The MR test, the "M" portion of the four IMViC tests, is used to identify enteric

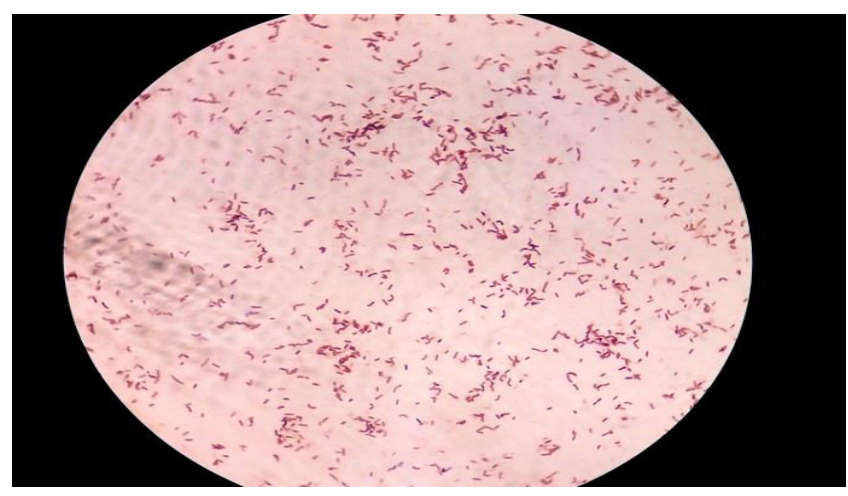

Fig 3: Gram Negative rod shape bacteria.

bacteria based on their pattern of glucose metabolism. All enterics initially produce pyruvic acid from glucose metabolism. The isolated bacteria Salmonella were MR positive.

Voges-Proskauer test: Voges-Proskauer is a test used to detect acetoin in a bacterial broth culture. A cherry red color indicates a positive result, while a yellow-brown color indicates a negative result. The isolated bacteria Salmonella were VP negative.

Indole test: The indole test is a biochemical test performed on bacterial species. A positive result is shown by the presence of a red or red-violet color in the surface alcohol layer of the broth. A negative result appears yellow. The isolated bacteria Salmonella were indole negative.
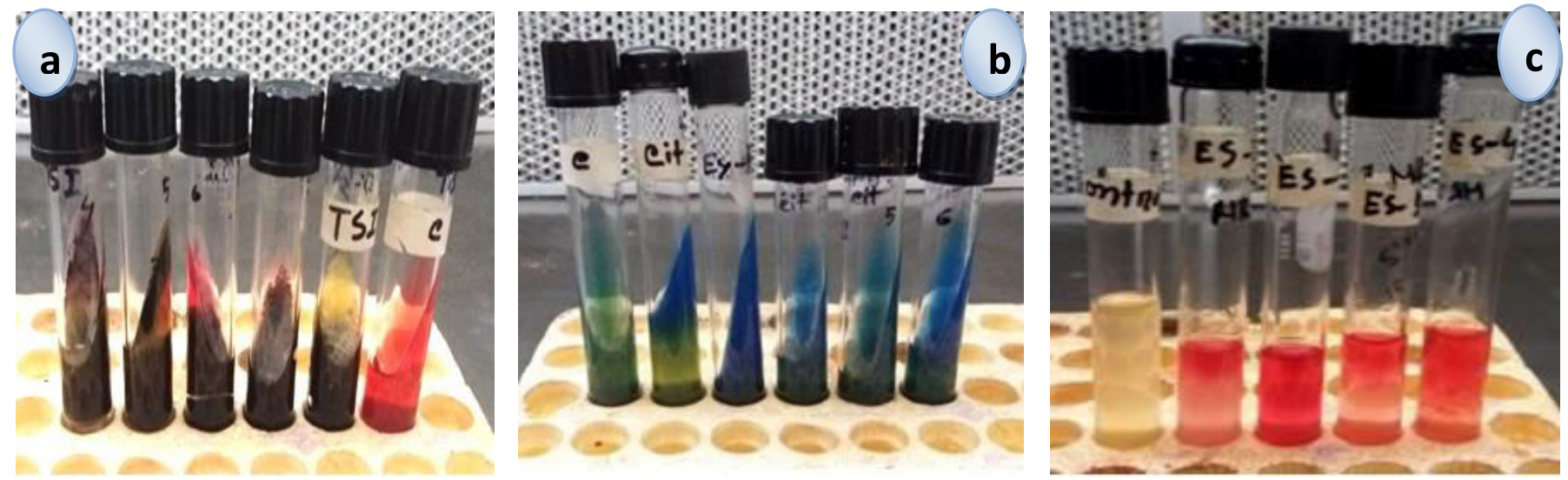

Fig 4: (a) TSI test (Right showing negative control); (b) Citrate test (Left showing control) (c) Methyl Red test (Left showing negative control). 
Motility test: Non-motile bacteria generally give growths that are confined to the stab-line, have sharply defined margins. Motile bacteria move about with structures called flagella. The isolated bacteria Salmonella were motility positive.
Oxidase test: This test depends on the presence of cytochrome oxidase in bacteria that will catalyze the transport of electrons between electron donors and redox dye. The isolated bacteria Salmonella were oxidase negative.
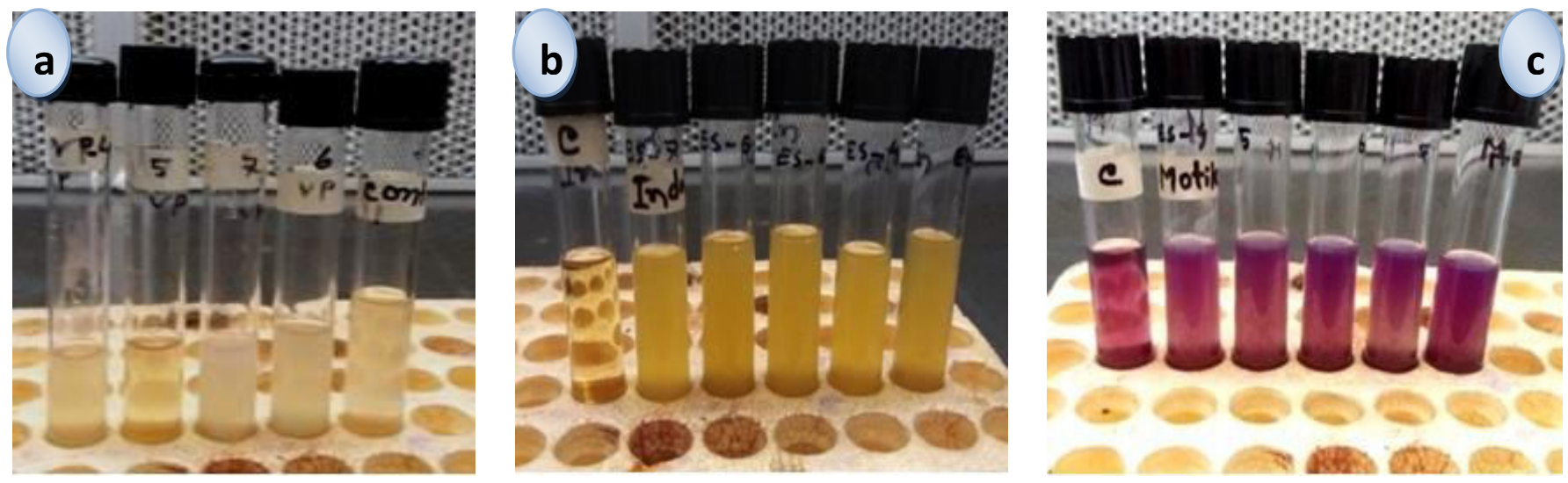

Fig 5: (a) Voges-Proskauer test (Right showing control); (b) Indole test (Left tube showing control) and (c) Motility test (Left showing control).

Table 3: Biochemical characterization of isolates.

\begin{tabular}{llllllllll}
\hline Organism & Indole & TSI & Citrate & Motility & Urease & MR & VP & Oxidase & Catalase \\
\hline Salmonella spp & - & + & + & + & - & + & - & - & + \\
\hline
\end{tabular}

Table 4: Biochemical tests Result: (For confirmation of Salmonella spp.)

\begin{tabular}{|c|c|c|c|c|c|c|c|c|c|c|}
\hline 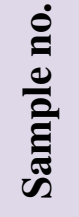 & $\begin{array}{l}\frac{\varrho}{\theta} \\
\stackrel{\Xi}{\Xi}\end{array}$ & $\bar{D}$ & 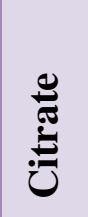 & 胥 & 岕 & $\stackrel{\Sigma}{\Sigma}$ & $\hat{z}$ & 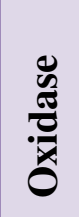 & 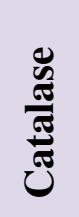 & Result \\
\hline 1 & - & + & + & + & - & + & - & - & + & Salmonella spp \\
\hline 2 & - & + & + & + & - & + & - & - & + & Salmonella spp \\
\hline 3 & - & + & + & + & - & + & - & - & + & Salmonella spp \\
\hline 4 & - & + & + & + & - & + & - & - & + & Salmonella spp \\
\hline 5 & - & + & + & + & - & + & - & - & + & Salmonella spp \\
\hline 6 & - & + & + & + & - & + & - & - & + & Salmonella spp \\
\hline 7 & - & + & + & + & - & + & - & - & + & Salmonella spp \\
\hline 8 & - & + & + & + & - & + & - & - & + & Salmonella spp \\
\hline 9 & - & + & + & + & - & + & - & - & + & Salmonella spp \\
\hline 10 & - & + & + & + & - & + & - & - & + & Salmonella spp \\
\hline
\end{tabular}




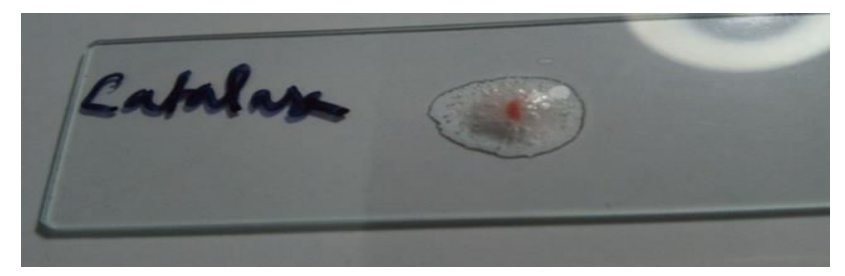

Fig 6: Catalase test.

Catalase test: The catalase test is one of the three main tests used by microbiologists to identify species of bacteria. If the mixture produces bubbles or froth, the organism is said to be 'catalase-positive'. If not, the organism is 'catalase-negative'. The isolated bacteria Salmonella were catalase positive.

Antibiotic sensitivity test result: In this study, the size of zone of inhibition of every antibiotic

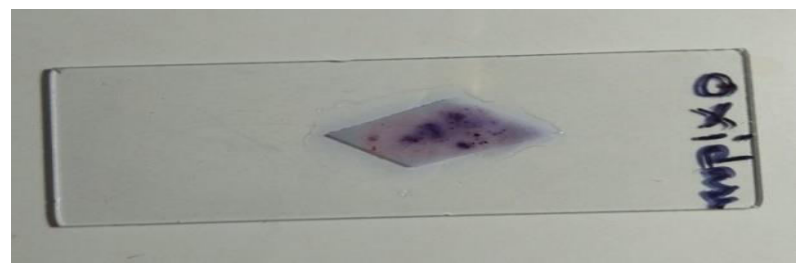

Fig 7: Oxidase test.

disc was measured in millimeter and while those zones of inhibition compared with zone diameter interpretive standards from C LSI (2000) (Table 5). The highest resistance rates were recorded against ampicillin (80\%), chloramphenicol (60\%) and tetracycline $(46.66 \%)$, while the highest sensitivity rates $(100 \%)$ were recorded against co-trimoxazole and ciprofloxacin.

Table 5: Antibiotic sensitivity test result: Zone Diameter, mm

\begin{tabular}{|c|c|c|c|c|c|c|}
\hline \multirow{2}{*}{ 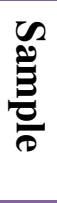 } & COT & $\mathrm{C}$ & CIP & AMP & GEN & TE \\
\hline & $\begin{array}{l}\mathrm{S}:>30 \mathrm{~mm}, \\
\mathrm{I}: 28 \mathrm{~mm}, \\
\mathrm{R}:<22 \mathrm{~mm}\end{array}$ & $\begin{array}{l}\mathrm{S}:>18 \mathrm{~mm}, \mathrm{I}: \\
13-14 \mathrm{~mm}, \\
\mathrm{R}:<12 \mathrm{~mm}\end{array}$ & $\begin{array}{l}\mathrm{S}:>31 \mathrm{~mm}, \\
\mathrm{I}: 21-30 \mathrm{~mm}, \\
\mathrm{R}:<20 \mathrm{~mm}\end{array}$ & $\begin{array}{l}\mathrm{S}:>17 \mathrm{~mm}, \\
\mathrm{I}: 14-16 \mathrm{~mm}, \\
\mathrm{R}:<13 \mathrm{~mm}\end{array}$ & $\begin{array}{l}\mathrm{S}:>15 \mathrm{~mm}, \mathrm{I}: 13- \\
14 \mathrm{~mm}, \\
\mathrm{R}:<12 \mathrm{~mm}\end{array}$ & $\begin{array}{l}\mathrm{S}:>15 \mathrm{~mm}, \mathrm{I}: 12- \\
14 \mathrm{~mm}, \\
\mathrm{R}:<10 \mathrm{~mm}\end{array}$ \\
\hline 1 & $\begin{array}{l}\mathrm{S} \\
38 \mathrm{~mm}\end{array}$ & $\begin{array}{l}\mathrm{R} \\
11 \mathrm{~mm}\end{array}$ & $\begin{array}{l}\mathrm{S} \\
38 \mathrm{~mm}\end{array}$ & $\begin{array}{l}\mathrm{R} \\
12 \mathrm{~mm}\end{array}$ & $\begin{array}{l}\mathrm{S} \\
16 \mathrm{~mm}\end{array}$ & $\begin{array}{l}\mathrm{S} \\
16 \mathrm{~mm}\end{array}$ \\
\hline 2 & $\begin{array}{l}\mathrm{S} \\
36 \mathrm{~mm}\end{array}$ & $\begin{array}{l}\mathrm{I} \\
13 \mathrm{~mm}\end{array}$ & $\begin{array}{l}\mathrm{S} \\
35 \mathrm{~mm}\end{array}$ & $\begin{array}{l}\mathrm{R} \\
11 \mathrm{~mm}\end{array}$ & $\begin{array}{l}\mathrm{R} \\
11 \mathrm{~mm}\end{array}$ & $\begin{array}{l}S \\
16 \mathrm{~mm}\end{array}$ \\
\hline 3 & $\begin{array}{l}\mathrm{S} \\
33 \mathrm{~mm}\end{array}$ & $\begin{array}{l}\mathrm{I} \\
13 \mathrm{~mm}\end{array}$ & $\begin{array}{l}\mathrm{I} \\
25 \mathrm{~mm}\end{array}$ & $\begin{array}{l}\mathrm{R} \\
12 \mathrm{~mm}\end{array}$ & $\begin{array}{l}\mathrm{S} \\
16 \mathrm{~mm}\end{array}$ & $\begin{array}{l}\mathrm{I} \\
13 \mathrm{~mm}\end{array}$ \\
\hline 4 & $\begin{array}{l}\mathrm{S} \\
36 \mathrm{~mm}\end{array}$ & $\begin{array}{l}\mathrm{R} \\
11 \mathrm{~mm}\end{array}$ & $\begin{array}{l}\mathrm{S} \\
38 \mathrm{~mm}\end{array}$ & $\begin{array}{l}\mathrm{I} \\
15 \mathrm{~mm}\end{array}$ & $\begin{array}{l}\mathrm{R} \\
11 \mathrm{~mm}\end{array}$ & $\begin{array}{l}\mathrm{R} \\
9 \mathrm{~mm}\end{array}$ \\
\hline 5 & $\begin{array}{l}\mathrm{S} \\
38 \mathrm{~mm}\end{array}$ & $\begin{array}{l}\mathrm{I} \\
14 \mathrm{~mm}\end{array}$ & $\begin{array}{l}\mathrm{S} \\
33 \mathrm{~mm}\end{array}$ & $\begin{array}{l}\mathrm{R} \\
12 \mathrm{~mm}\end{array}$ & $\begin{array}{l}\mathrm{R} \\
11 \mathrm{~mm}\end{array}$ & $\begin{array}{l}\mathrm{R} \\
9 \mathrm{~mm} \\
\end{array}$ \\
\hline 6 & $\begin{array}{l}\mathrm{S} \\
33 \mathrm{~mm}\end{array}$ & $\begin{array}{l}\text { I } \\
14 \mathrm{~mm}\end{array}$ & $\begin{array}{l}\mathrm{S} \\
38 \mathrm{~mm}\end{array}$ & $\begin{array}{l}\mathrm{R} \\
11 \mathrm{~mm}\end{array}$ & $\begin{array}{l}\text { I } \\
13 \mathrm{~mm}\end{array}$ & $\begin{array}{l}\mathrm{R} \\
9 \mathrm{~mm}\end{array}$ \\
\hline 7 & $\begin{array}{l}\mathrm{S} \\
32 \mathrm{~mm}\end{array}$ & $\begin{array}{l}\mathrm{R} \\
10 \mathrm{~mm}\end{array}$ & $\begin{array}{l}\mathrm{S} \\
32 \mathrm{~mm}\end{array}$ & $\begin{array}{l}\mathrm{I} \\
15 \mathrm{~mm}\end{array}$ & $\begin{array}{l}\mathrm{R} \\
11 \mathrm{~mm}\end{array}$ & $\begin{array}{l}\mathrm{I} \\
13 \mathrm{~mm}\end{array}$ \\
\hline 8 & $\begin{array}{l}\mathrm{S} \\
34 \mathrm{~mm}\end{array}$ & $\begin{array}{l}\mathrm{R} \\
10 \mathrm{~mm}\end{array}$ & $\begin{array}{l}\mathrm{S} \\
38 \mathrm{~mm}\end{array}$ & $\begin{array}{l}\mathrm{R} \\
12 \mathrm{~mm}\end{array}$ & $\begin{array}{l}\mathrm{R} \\
12 \mathrm{~mm}\end{array}$ & $\begin{array}{l}\mathrm{R} \\
7 \mathrm{~mm}\end{array}$ \\
\hline 9 & $\begin{array}{l}\mathrm{S} \\
36 \mathrm{~mm}\end{array}$ & $\begin{array}{l}\mathrm{I} \\
14 \mathrm{~mm}\end{array}$ & $\begin{array}{l}\mathrm{S} \\
38 \mathrm{~mm}\end{array}$ & $\begin{array}{l}\mathrm{R} \\
10 \mathrm{~mm}\end{array}$ & $\begin{array}{l}\mathrm{I} \\
14 \mathrm{~mm}\end{array}$ & $\begin{array}{l}\mathrm{I} \\
12 \mathrm{~mm}\end{array}$ \\
\hline $\begin{array}{l}1 \\
0\end{array}$ & $\begin{array}{l}\mathrm{S} \\
38 \mathrm{~mm}\end{array}$ & $\begin{array}{l}\mathrm{R} \\
10 \mathrm{~mm}\end{array}$ & $\begin{array}{l}\mathrm{S} \\
37 \mathrm{~mm}\end{array}$ & $\begin{array}{l}\mathrm{I} \\
15 \mathrm{~mm}\end{array}$ & $\begin{array}{l}\mathrm{R} \\
10 \mathrm{~mm}\end{array}$ & $\begin{array}{l}\mathrm{R} \\
8 \mathrm{~mm}\end{array}$ \\
\hline
\end{tabular}



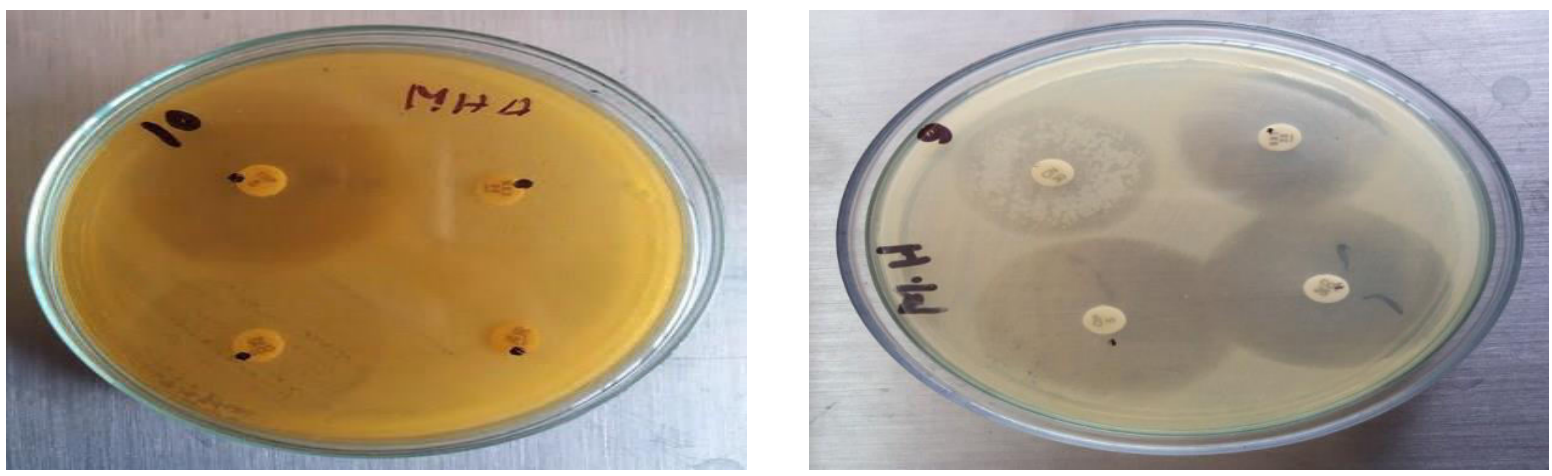

Fig 8: Antibiotic sensitivity test of salmonella.

The resistance rate against tetracycline (46.66\%) was similar to the result of Mahammad et al., who reported approximately 52\% of resistance. However, higher resistance rate was reported by Samah who recorded resistance rate of $92.9 \%$. The resistance rate against chloramphenicol $(60 \%)$ was in accordance with the result of Manie et al., who reported a rate of approximately $62 \%$ resistance against antimicrobial drugs. In the present study ciprofloxacin \& co-trimoxazole works much better than other antibiotics used.

Table 6: Percentages of resistances patterns of Salmonella.

\begin{tabular}{|c|c|c|c|}
\hline Name of Antibiotics & $\begin{array}{c}\text { Percentages of } \\
\text { Sensitivity }(\boldsymbol{\%})\end{array}$ & $\begin{array}{c}\text { Percentages of } \\
\text { Intermediate resistance }\end{array}$ & $\begin{array}{c}\text { Percentages of } \\
\text { Resistance } \mathbf{( \% )}\end{array}$ \\
\hline Cotrimoxazole & 100 & 0 & 0 \\
\hline Chloramphenicol & 0 & 50 & 50 \\
\hline Ciprofloxacin & 90 & 10 & 0 \\
\hline Ampicillin & 0 & 30 & 60 \\
\hline Gentamicin & 20 & 20 & 50 \\
\hline Tetracycline & 20 & 30 & 70 \\
\hline
\end{tabular}

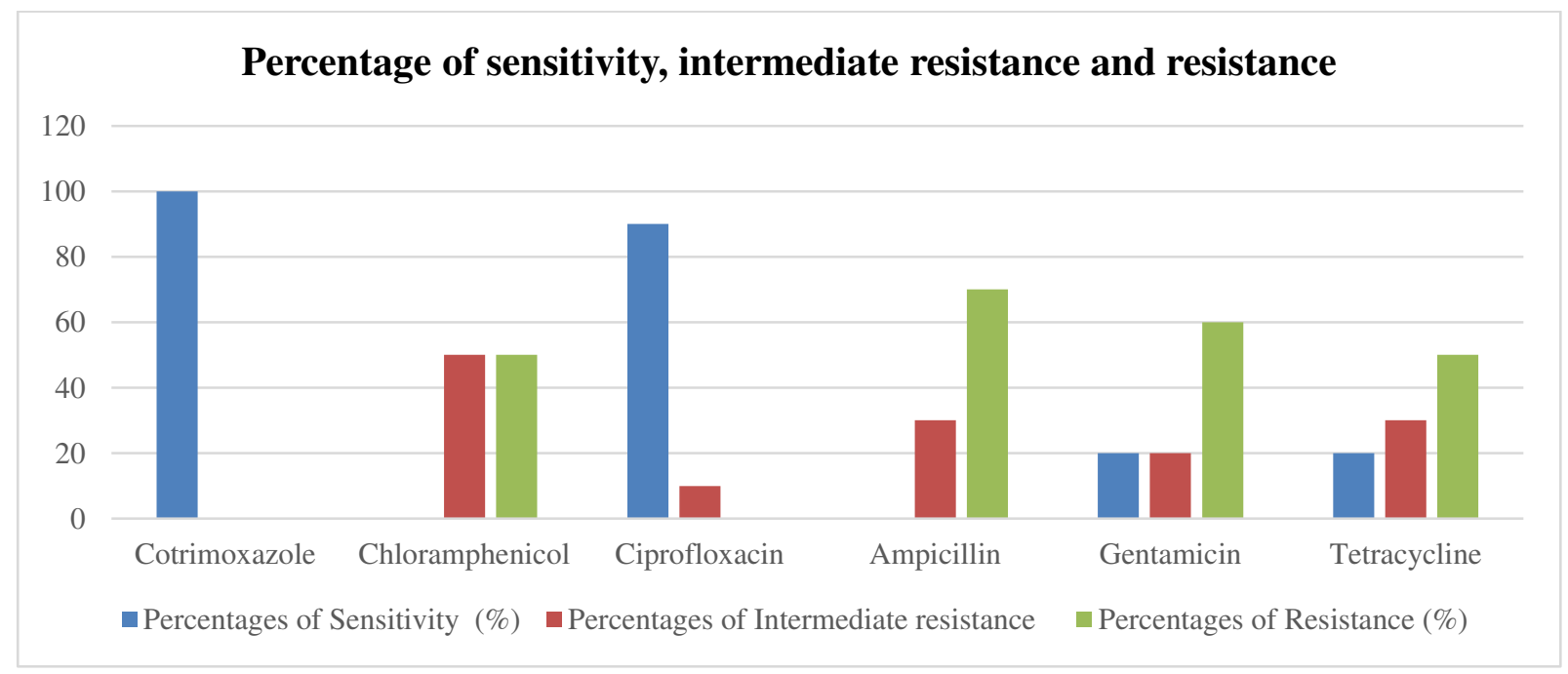

Fig 9: Percentage of sensitivity, intermediate resistance and resistance of Salmonella spp. 


\section{CONCLUSION}

Salmonella contamination of eggs is a complex issue affected by variables at each stage of the food production process. Eggs associated Salmonellosis is an important public health problem in the world we have to consider some of the point that eggs offered for sale must be free of faces, dirt and stains. Enteric fever is mostly caused by members of serovar Typhi and Paratyphi A, both of which only infect humans (Uzzau et al., 2000). Gastroenteritis on the other hand is most often caused by Enteritidis in humans and Typhimurium in animals (Galanis et al., 2006), although both serovars can infect a wide range of hosts (Uzzau et al., 2000). However, the usefulness of the serological classification of $S$. enterica is undermined by the fact that unrelated strains sometimes belong to the same serovar. Egg farms must be regularly visited by field inspectors to monitor bird health by recording feed and appearance. In particular the risk of air pollution with bacteria, fungi, dust, endotoxins and ammonia, this is significantly higher in alternative

\section{REFERNCES}

1. Ahmed F., Ahmad I., Khan M.S. (2008). Screening of free-living rhizospheric bacteria for their multiple plant growth promoting activities. Microbiol. Res., 163: 173-18. https://doi.org/10.1016/j.micres.2006.04.001

2. Aneja K.R. (2003). Staining and biochemical techniques. In: Experiments in microbiology, plant pathology and biotechnology, New Age International Ltd, Publishers, New Delhi.

3. Cappuccino J. C., Sherman N. (2005). In: Microbiology: A Laboratory Manual, $3^{\text {rd }}$ Ed. Benjamin Pub. Co. New York, 125-179.

4. Cogan T., Humphrey T. (2003). The rise and fall of Salmonella Enteritidis in the UK. J. of Appl. Microbiol. 94: 114-119. https://doi.org/10.1046/j.1365-2672.94.s1.13.x than in conventional systems (Rodenburg et al., 2005; Vučemilo et al., 2008). Efforts including critical control point programs in food production are needed to reduce the incidence of Salmonella in food. Consumers-awareness efforts would protect public health from food borne and Salmonellosis.

\section{ACKNOLEDGEMENTS}

This research was financially supported with proper guidance and helping for data analysis in the Department of Microbiology of the Gono Bishwabidyalay, Savar, Dhaka, Bangladesh. Heartiest thanks to the authority of Gono Bishwabidyalay for helping us to conduct the research work.

\section{CONFLICTS OF INTEREST}

The author (s) declared no potential conflicts of the interest with respect to the research, authorship and/or publication of this article.

5. De Reu K., Messens W., Herman L. (2008). Bacterial contamination of table eggs and the influence of housing systems. World's Poultry Science Journal, 64: 6-19.

6. Didelot X., Bowden R., Street T., Golubchik T., McVean G. (2011). Recombination and Population Structure in Salmonella enterica. PLoS Genet., 7(7): e1002191. https://doi.org/10.1371/journal.pgen.1002191

7. Galanis E., Lo Fo Wong DM, Patrick ME., Cieslik A. (2006). Web based surveillance and global Salmonella distribution, 2000-2002. Emerg Infect Dis., 12: 381-388

8. Gonzalez-Espada W., Zaras, D. (2011). Evaluation of the impact of the National 
Weather Center REU program compared with other undergraduate research experiences. $15^{\text {th }}$ Symposium on Education, Amer Meteorolog Soc. Atlanta.

9. Herikstad H., Motarjemi Y., Tauxe R. V. (2002). Salmonella surveillance: a global survey of public health sero-typing. Epidemiol. Infect, 129: 1-8. https://doi.org/10.1017/s0950268802006842

10. Kamaruddin R., Shabudin A., Iberahim H. (2012). Halal Compliance Critical Control Point (HCCCP) Analysis of Processed Food. Proceedings of 2012 IEEE Business, Engineering \& Industrial Applications Colloquim.

11. Kenneth F. Schaffner. (2017). University of Pittsburgh Department of History and Philosophy of Science website. University of Pittsburgh. Retrieved, 03-11.

12. Md. Ekhlas Uddin, H. M. Faruquee, Md. Firoz Alam. (2014). Isolation and characterization of proteases enzyme from locally isolated Bacillus sp. American J. of Life Sciences. 2(6): 338-344. https://doi.org/10.11648/j.ajls.20140206.12

13. Messens W., Grijspeerdt K., Herman L. (2005). Egg shell penetration by Salmonella: A review. World's Poult. Sci. J., 61: 71-85

14. Rodenburg T.B., Tuyttens F.A.M., Sonck B., Reu De K., Herman L. and Zoons J. (2005).
Welfare, health and hygiene of laying hens housed in furnished cages and in alternative housing systems. J. of Appl Animal Welfare Sci. 8: 211-226.

https://doi.org/10.1207/s15327604jaws0803_5

15. Tortora GA. (2008). Microbiology: An Introduction, 9th ed. Pearson. pp. 323324. ISBN 8131722325.

16. Uzzau S., Brown DJ., Wallis T., Rubino S., Leori G. (2000). Host adapted serotypes of Salmonella enterica. Epidemiol Infect. 125: 229-255-

17. Vučemilo M., Granić K., Orct T. (2008). Effect of microclimate on the airborne dust and endotoxin concentration in a broiler house. Czech J. of Animal Sci. 53: 83-89. https://www.agriculturejournals.cz/publicFiles/007 45.pdf

18. William N., Wilson J., Hazel S., Goetzmann (2003). Non-typhoidal Salmonella in United Kingdom Badgers: Prevalence and spatial distribution. Appl and Environmental Microbiol. 69: 4312-4315.

19. Yan S., Pendrak M., Abela-Ridder B. (2003). An overview of Salmonella typing public health perspectives. Clin and Appl Immunol Rev. 4: 189-204.

https://www.ncbi.nlm.nih.gov/pmc/articles/PMC6 004630/

Citation: Rahman MA, Haque A, Ahmad T, Mahmud S, Sohana SN, Hossain MR, Barman NC, Badiruzzaman M, Hossain T, Haque MS, Uddin ME, and Ahmed R. (2019). Isolation, identification, and antibiotic sensitivity pattern of Salmonella spp from locally isolated egg samples. Am. J. Pure Appl. Sci., 1(1), 1-11. https://doi.org/10.34104/ajpab.019.019111 @) @ 